\title{
Mary and the Catholic Church in England, 1854-1893
}

\begin{abstract}
The article offers description of the Marianism of the English Catholic Church - in particular as manifested in the celebration of the definition of the doctrine of the Immaculate Conception in 1854 and the solemn consecration of England to the Virgin in 1893 - in order to comment on the community's (and more particularly, its leadership's) changing perception of its identity and situation over the course of the later nineteenth century. In doing so, it places particular emphasis on the presence of apocalyptic belief, reflective and supportive of a profound alienation from contemporary English society, which was fundamental in shaping the Catholic body's modern history.
\end{abstract}

\section{Introduction}

Frederick Faber, perhaps the most important of the writers to whom one should turn in attempting to grasp more than an exterior view of English Catholicism in the Victorian era, was constantly anxious to remind his audiences that Marian doctrine and devotion were fundamental and integral to Catholicism. As such, the Mother of God was necessarily to be found "everywhere and in everything" among Catholics. Non-Catholics, he noted, were disturbed to find her introduced in the most "awkward and unexpected" places. ${ }^{1}$ Faber's assertion, it might be remarked, seems to be extensively supported by the writings of present-day historians. We need look no further than to writings on a sub-theme of the history of Marianism - that of apparitions — and to the period spoken of in the present article to make the point. Fine studies of Marian apparitions have cast much needed light on extremely varied and interesting

1. F. W. Faber, Notes on Doctrinal and Spiritual Subjects, ed. J. E. Bowden (London: Thomas Richardson and Son, [1866]), 2: 33. His audiences certainly included Anglicans with Catholic sympathies, who feared that it was so. Faber thought it best, lest they deceived themselves that the Catholic Church could negotiate its doctrine, to take a confrontational stance on what Pusey later described as the "crux of the Roman system," as it diverged from their own thought. See J. H. Newman, A Letter to the Rev. E.B. Pusey, D.D. on his Recent Eirenicon, 2nd ed. (London: Longmans, Green, Reader, and Dyer, 1866), 26.

Cadoc Leighton is an Associate Professor of European History at Bilkent University, Ankara, Turkey. 
aspects of the life of Germany in the era of the Kulturkampf; of France under its Second Empire and Third Republic; and of Ireland (and particularly Connacht) at the time of the Land War. ${ }^{2}$ It is thus hardly overly sanguine to believe that the study of its Marianism will offer some increased understanding of the Catholic part of the ecclesiastical world in England's Victorian age, at least of the minds of its leadership, which articulated its Marian beliefs.

A focus on this largely clerical leadership was for long allowed to direct the general narrative of the Catholic institution in the nineteenth century. This narrative is doubtless most clearly set out in the work of Derek Holmes: it was, he reported bitterly, the story of "the failure of Liberal Catholicism," succeeded by "the establishment of Ultramontanism" and "the rise of Triumphalism."3 The academic writing of the later twentieth century on the nineteenth-century English Catholic Church was often pervaded by a concern with party conflict: a veritable rage of party. ${ }^{4}$ Rosemary Mitchell observes that a narrative reflecting these preoccupations has "now been rightly challenged" by historians, notably John Bossy and Gerald Connolly, more concerned with the Catholic community as a whole rather than merely those who aspired to direct it. ${ }^{5}$ Still, that the nineteenth century did see "the establishment of Ultramontanism" (and that some did, rather ineffectually, express discomfort with the ascendant trends), can hardly be questioned. ${ }^{6}$ Historiographical synthesis is likely when Ultramontanism's success is seen not as the triumph of a party (it was the movement's critics alone who so depicted it), but, in England, as a local participation in a process of change that constitutes the emergence of modern from early modern Catholicism. For reference to that process and its products

2. D. Blackbourn, Marpingen: Apparitions of the Virgin Mary in Nineteenth-Century Germany, 1st American ed. (New York: Alfred A. Knopf, 1994); R. Harris, Lourdes: Body and Spirit in the Secular Age (London: Allen Lane, 1999); and E. Hynes, Knock: the Virgin's Apparition in Nineteenth-Century Ireland (Cork: Cork University Press, 2008).

3. See the chapter headings of J. D. Holmes, More Roman than Rome: English Catholicism in the Nineteenth Century (London: Burns and Oates; Shepherdstown, VA: Patmos Press, 1978). A slightly later survey by Edward Norman begins by indicating its fundamental conformity to Holmes' depiction. See E. Norman, The English Catholic Church in the Nineteenth Century (Oxford: Clarendon Press, 1984), v.

4. The attention of this writing to the theme of parties, and particularly to those which represented resistance to the prevailing current of the era, cannot be said to have been clarifying. Thus, for example, Frederick Cwiekowski found it necessary to introduce his readers to Ultramontanists, "Old Catholics," "Anglo-Gallicans," and "Catholic Liberals" and their struggles in the introductory chapter of F. Cwiekowski, The English Bishops and the First Vatican Council (Louvain: Publications Universitaires de Louvain, 1971). Damien McElwrath had found also a party of converts (consisting of both Ultramontanists and Liberal Catholics), in conflict Old Catholics, though with a "middle or neutral element" between them. See D. McElwrath, The Syllabus of Pius IX: Some Reactions in England (Louvain: Publications Universitaires de Louvain, 1964), 6-9.

5. R. Mitchell, Picturing the Past: English History in Text and Image (Oxford: Clarendon Press, 2000), 173-74. See also G. Parsons, "Victorian Roman Catholicism: Emancipation, Expansion and Achievement," in Religion in Victorian Britain, ed. G. Parsons (Manchester: Manchester University Press, 1988), vol. 1, ch. 4.

6. However, Mary Heiman, attempting to reduce the parties in significant conflict to two, claims that the Ultramontanists were only the "supposed ... winners," a view her work supports by questioning "the supposed adoption" of their devotional practices. It is difficult to see in this, though, more than a capacity in Ultramontanism to establish itself in pre-existing religious cultures. See M. Heiman, Catholic Devotion in Victorian England (Oxford: Clarendon Press, 1995), 4-5, 8 and ch. 5. 
the name "New Catholicism" has lately become common. ${ }^{7}$ Perhaps "Ultramontanism" could, with adequate definition, serve as well. ${ }^{8}$

A pre-eminent characteristic of the New Catholicism was the manifestation of a willingness on the part of the ecclesia docens to respond to and identify with the felt needs and impulses of the ecclesia discens. This willingness was already becoming apparent in the latter part of the eighteenth century. As it was confirmed in the age of the Revolution and afterwards, it made inevitable, we may here add, an immense approved and well-directed intensification of Marian devotion and thought. ${ }^{9}$ In popular manifestations of such trends, as Christopher Clark emphasises, it remained the case that "[c]lerical initiatives were crucial." ${ }^{10}$ Indeed, the study of the role of the clergy and its significance is necessarily of considerable interest to students of the New Catholicism, if only because of the role of anti-clericalism in forming the conflict that so profoundly determined its nature. ${ }^{11}$ In brief, no widening of the interests of historians of nineteenth-century English Catholic history should or can disentangle its lay and clerical components or diminish the importance of the latter. Nor, happily, does it seem to do so. We may note, for example, in Connolly's exemplary study the nineteenth-century Catholic life of the twin towns of Manchester and Salford, discussion of the "rise of the Catholic clergy" and its consequences for the community as a whole. ${ }^{12}$ Consideration of this phenomenon perhaps renders unnecessary apology for the domination of clerical sources in this limited essay, which is structured around two papally initiated and clerically directed events. The dates included in its title refer to these: the papal definition of the dogma of the Immaculate Conception and the consecration of England to Mary Immaculate, performed by Cardinal Vaughan, which can certainly be taken as the most notable public celebrations of the Marian cult in nineteenth-century England.

In the passages just cited from Connolly's study, the "rise of the Catholic clergy" is related to the abandonment of an "instinctive integrationist mentality" and the increased adoption of an assertion of Catholic separateness from a reprobated surrounding society. Here the author strikes on a prominent and

7. For the significance of this term see C. Clark, "The New Catholicism and the European Culture Wars," in Culture Wars: Secular-Catholic Conflict in Nineteenth-Century Europe, ed. C. Clark and W. Kaiser (Cambridge: Cambridge University Press, 2003), ch. 1.

8. This point is briefly discussed in C. Leighton, "John Milner, History and Ultramontanism," Archivium Hibernicum 63 (2010): 350.

9. L. Châtellier, The Religion of the Poor: Rural Missions in Europe and the Formation of Modern Catholicism, c. 1500-c. 1800, trans. B. Pearce (Cambridge: Cambridge University Press and Maison des Sciences de l'Homme, 1997), ch. 12.

10. Clark, "New Catholicism," 15-16.

11. Clark's "New Catholicism" is complemented and illuminated by Kaiser's study of European anti-clericalism - an obviously necessary preliminary to the descriptions of particular conflicts, described by other contributors to their book. It might be suggested in passing, that Kaiser's inclusion of Gallicans and Liberal Catholics among Europe's anti-clerical forces may afford fresh understanding even of the English party conflicts referred to above. See W. Kaiser, "Clericalism that is our enemy! European anti-Clericalism and the Culture Wars," in Culture Wars, ed. Clark and Kaiser, , ch. 2. See especially 50-52.

12. G. Connolly, "The Transubstantiation of Myth: Towards a New Popular History of Nineteenth-Century Catholicism in England" Journal of Ecclesiastical History 35, no. 1 (1984): 84-87 and 94-99. 
central theme in recent discussion of the New Catholicism or Ultramontanism: as states and societies were perceived as increasingly inimical to the practice of the Catholic faith and its advancement, Catholics and their leaders grew closer, in response to an unfriendly environment, "in which both clergy and laity worked together to create a 'society apart." "13 In the Netherlands, where Catholics could ally themselves with Protestants equally alienated from a liberal state, the desire to create societies within society achieved an enduring political foundation and an institutional form that came to be referred to as pillarisation or, in Dutch, verzuiling. ${ }^{14}$ In England the task of building and defending a distinct Catholic society was attended with a lesser, but real degree success. A lack of sympathy with this labour is disclosed in the now longestablished practice in popular writing of speaking pejoratively of a "ghetto mentality" in British Catholicism. There has been little inclination either to consider empathetically the religious foundations of the much deprecated phenomenon or to estimate its historical progress and retardation — and the anxieties provoked by the latter, a matter addressed in the latter part of this article. The Catholic community's separation from the mainstream of British life may be partially accounted for by that community's circumstances and inherent characteristics, such as the vibrant English anti-Catholic tradition, periodically stirred by events at home and abroad, or its ethnic composition. However, it was also purposefully adopted and sustained, on the basis of deep religious belief and historical reflection. It will, it is hoped, be seen that Marian beliefs and devotion in particular, chiefly as expressed in print and liturgy, do much to expose this pattern of thought.

\section{The Meaning of the Immaculate Conception}

The devotion to Mary under the title of her Immaculate Conception stood together with devotions to Christ, in his Passion, in the Eucharist and as the Sacred Heart, as a pre-eminent characteristic of Catholic practice in the age of Ultramontanism. However, contemporaries noted that the devotion to the Immaculate Conception possessed an integral relationship to Ultramontanism, not possessed by the other, Christocentric devotions just mentioned. Contemporaries, such as Gladstone, indeed perceived the definition of 1854 with the Syllabus of Errors (1864) and the definition of the doctrine of papal infallibility (1870) as the pre-eminent landmarks in the recent history of "the dominant party" in the Catholic Church. It is, though, unlikely that in speaking thus of the definition of the Immaculate Conception, Gladstone had in mind much more than the bold assertion of papal authority utilised in the act of definition. ${ }^{15}$ Not that the use made of papal authority in declaring the doctrine to be de fide

13. R. Schaefer, "Program for a New Catholic Wissenschaft: Devotional Activism and Catholic Modernity in the Nineteenth Century," Modern Intellectual History 4, no. 3 (2007): 433-34.

14. The concept of verzuiling is conveniently explained in J. C. H. Blom, "The Netherlands since 1830," in History of the Low Countries, ed. J. C. H. Blom and E. Lamberts, new ed. (New York: Berghahn, 2006), 418-25 and 431-39.

15. W. E. Gladstone, The Vatican Decrees in their Bearing on Civil Allegiance: A Political Expostulation (London: John Murray, 1874), 14-18. 
was unimportant to Catholics either. Wiseman perceived this matter as likely to provoke Gallican dissent and discomfort among some converts from Anglicanism. When he wrote of the definition, he did so with this in mind, emphasising heavily the extent of the consultation undertaken before the definition and the unanimity of the Catholic world manifested in the event. ${ }^{16}$ The view circulated among other notables, such as Bishop William Ullathorne ${ }^{17}$ and Father Faber, ${ }^{18}$ and their writings on the topic reflected the same - as it soon appeared exaggerated pastoral concern. As the earlier years of Pius IX's pontificate went on, reference to the Immaculate Conception was ever more frequently utilised in celebration of papal infallibility. In truth, though, the manner in which the dogma was defined constituted only a superficial manifestation of the profound importance of the cultus of the Immaculate Conception in the history of the nineteenth- and twentieth-century papacy and indeed the whole Catholic Church in the period. In speaking of England, an understanding of the cultus's significance allows a far firmer grasp of an ethos which, with other circumstances of the times, gave the Catholic body a remarkable sense of purpose and solidarity and allowed an embracing of its alienation from a generally hostile society around it.

Catholic writers of the nineteenth century perceived, with some justification, that the propagation of Marianism had constituted a notable aspect of the previous century's struggle against the Enlightenment, ${ }^{19}$ which was likely to be described in commendably broad terms. Here, secular historiography's favoured petite troupe of philosophes was reduced to a realistic status and the Enlightenment against which Marian devotion was a bulwark was constituted by "Jansenism, Gallicanism, Regalism, [and] Philosophism." ${ }^{20}$ However, the Marianism, theological and devotional, of the eighteenth century hardly singled out the title Immaculata. ${ }^{21}$ The church's experience of the Revolutionary era and the new century, together with the apocalyptic interpretation given to it, changed that. The Revolution was to be understood as a well-prepared and

16. N. Wiseman, Pastoral Letter ... Announcing the Definition of the Immaculate Conception of the Blessed Virgin Mary (London: T. Jones, 1855), 1-4.

17. W. B. Ullathorne, The Immaculate Conception of the Mother of God: An Exposition (London: Richardson and Son, 1855). See esp. ch. 18.

18. F. W. Faber, An Explanation of the Doctrine and Definition of the Immaculate Conception ... (London: C. Dolman, 1855), 19-22. As Faber put it, the matter, when raised, gave him "no difficulty because I took the line of not arguing the ultramontane side, but showed the clamorous applause and acceptation of the ecclesia dispersa as satisfying even old Gallicanism." See Faber to John Henry Newman, 16 March 1855, Correspondence, vol. 3, no. 149, and, additionally, Faber to Ullathorne, 12 March 1855 [copy], Correspondence, vol. 22, f. 58, Archives of the London Oratory, Brompton [hereafter A. L. Orat.].

19. For exemplification of Marianism's capacity to become involved in the conflict of the period, see E. G. López, "La Devócion a la Madre Santísima de la Luz: un aspecto de la represión del jesuitismo en la España de Carlos III," Revista de Historia Moderna: Anales de la Universidad de Alicante 15 (1996): 213-32.

20. A. Berthe, Life of St. Alphonsus de' Liguori, trans. H. Castle (Dublin: James Duffy, 1905), 1: 377-98. See esp. 1: 383.

21. Alphonus de' Liguori (1696-1787), probably the Marian doctor most widely read in the nineteenth century, focused on the Virgin's role as co-redemptrix and the extension of this role, as mediatrix of grace. It was on this ground that he argued, as a secondary point, for her deliverance from original sin at her conception, as fitting preparation for her redemptive role. See A. de' Liguori, Glories of Mary (Clapham: Redemptorist Fathers, 1852), pt. 1, ch. 5 and pt. 2, discourse 1. 
consistently directed assault on the Christian faith and its attendant social and political structures by the adherents of philosophism. However, that creed had, well before 1789, been held to have its historical origins in the Protestant Reformation. The conspiracy was both immense and very old indeed; and its servants' labours to seize power - their energy undiminished as the nineteenth century went on - might easily be seen to be directed by a more than human vision. Thus the developments which the church identified as most noxious, as it surveyed the nineteenth century's cultural, intellectual, social, and political changes, might be understood most profoundly as anticipations and types of the coming reign of Antichrist or even as its commencement. ${ }^{22}$ As in France at the end of the eighteenth century, this could, it is true, be spoken of or even perceived as a mere human conspiracy: the conspiracy was that of the comite directeur, which Prince von Metternich sought so zealously to uncover. ${ }^{23}$ In any case, whether humanly or supernaturally directed, the movement of which this was the supposed wellspring called for moral condemnation by the church. It is thus that a present-day historian could accept the significance of the series of events pointed to by Gladstone, but amplify it by making clear that definition of the Immaculate Conception was to be regarded as the first of the major acts of a pontificate characterised by its struggle against "the Revolution"; that "social organization of sin" which came from the propagation of the principles of the philosophe and the Jacobin. However, albeit that the church's more authoritative declarations were less than explicit in identifying "the Revolution" as foreshadowing or preparing the way of Antichrist, that this interpretation of current events was prevalent must be regarded as influential. The doctrine that, uniquely among the redeemed, Mary had, in every moment and in every aspect of her life, triumphed over the power of sin, made plain her pre-eminent place in this apocalyptic conflict. The very act of defining the doctrine constituted a major event in the history of that conflict. It was, firstly, an act of devotion, in petition for aid by the whole church in its distress. Secondly, in such a solemn proclamation of Mary's freedom from original sin, there was a declaration of that sin's power: it debilitated reason and forever rendered absurdly ineffectual human efforts to improve the lot of humanity by means of political ideologies. ${ }^{24}$

It was, highly significantly, in his refuge at Gaeta, beyond the reach of the Roman Republic, that Pius IX took up the matter of the definition of the Immaculate Conception. In the years of preparation which followed, the pope made clear the contemporary significance of the doctrine, by seeking to unite the definition "alla condanna degli errori moderni.", 25 The perception of the errors of modernity by the court of Rome was, though, a particular one. As

22. C. D. A. Leighton, "Thomas Allies, John Henry Newman and Providentialist History," History of European Ideas 38, no. 2 (2012), pt. 4.

23. A. Sked, The Decline and Fall of the Habsburg Empire 1815-1918 (Harlow: Longman, 1989), 42.

24. R. de Mattei, Pius IX, trans. J. Laughland (Leominster: Gracewing, 2004), 103-108.

25. G. Martina, Pio IX, Miscellanea Historiae Ponificiae, vols. 38, 51 and 58 (Rome: Editrice Pontificia Gregoriana, 1974-1990), 2: 266. 
Edward Hales remarked, the errors that Pio Nono was to condemn in the "Syllabus were largely Cavour's, Mazzini's and Napoleon's." ${ }^{26}$ English Catholics might indeed, like Catholics elsewhere, sincerely lament when "the Holy City of the Catholics, the home of our affections ... [was] lying waste and desolate and in darkness" beneath the power of Italian insurgents. ${ }^{27}$ Yet, this was to survey a foreign battle-field, albeit one in the same war as that in which they also fought. They showed themselves most willing to respond to the Marian impulse from Pius IX, as an expression of their own religion. However, their response reflected their particularly English concerns, with an apocalyptic closely related to their vision for their own country and with their desire to prosecute their polemical conflict with what they perceived to be a decayed Protestantism and a nation being led to destruction by its own modern errors. This response, described below, well illustrates the profoundly reciprocal relationship between the papacy and embattled Catholic communities that everywhere constituted nineteenth-century Ultramontanism. If devotion and conformity to the Roman see increased in England, the English Catholic church gained from this, most basically and importantly, opportunities to nurture and sustain a greatly intensified sense of its own identity and purpose.

\section{The Immaculate Conception and England}

The papal act of definition on 8 December, 1854, and the events immediately surrounding it, in themselves, might be taken as pointing out the significance of the event, the receptiveness that the Roman initiative could find in England and the capacity of such initiatives to serve for the strengthening of the identity and sense of purpose of England's Catholic minority. The observance of the event in England was to centre on the London Oratory's church, recently removed to Brompton, and thus was given its character by the superior there, Father Faber. He was indeed one well suited to convey the intended meaning of the event. The Marianism that was at the heart of his devotional life and pervaded his religion was intimately related to that apocalyptic vision, in which the phenomena that the church's enemies lauded under the name of modernity were perceived as constituting an apocalyptic crisis. In the earliest period of his conversion to Catholicism, he, like many others, found in the recently rediscovered writings of Louis-Marie Grignion de Montfort both a key to the apocalyptic interpretation of his age and, in that, a means of his sanctification. ${ }^{28}$ Not that the series of sermons preached that December by Faber displayed preoccupation with apocalyptic themes: the praise of Mary was a more exalted

\footnotetext{
26. E. E. Y. Hales, Pio Nono: A Study in European Politics and Religion in the Nineteenth Century (London: Eyre and Spottiswood, 1954), xii.

27. Faber, Notes, 1: 355.

28. C. D. A. Leighton, "Finding Antichrist: Apocalypticism in Nineteenth-Century Catholic England and the Writings of Frederick Faber," Journal of Religious History 37, no. 1 (2013): 94-97. Faber quickly came to be held the "apostle . . . in England" of the doctrines preached by de Montfort, perhaps chiefly because of his translation of the French missionary's Traité de la vraie devotion à la sainte Vierge. A. P. J. Cruickshank [A Secular Priest, pseud.], "Translator's Preface," in [L-J.] Dalin, Life and Select Writings of . . Louis-Marie Grignon de Montfort . . . (London: Thomas Richardson, 1870), xxvii.
} 
and appropriately festive one. Still, they did clearly display that devotional and theological image of Mary which corresponded with her central and pervasive role in human history and its end, as Faber so often drew it. ${ }^{29}$ The true identity of Mary was not to be grasped unless she was depicted in relation to cosmic realities, in her relationship to the persons of the Trinity and the history of human salvation. Moving between theological reflection and visionary imagery to express this in a sermon on the Immaculate Conception, Faber saw human understanding of Mary overwhelmed by her cosmic glory. "Is it a creature or is it God whom I have described?" 30 The sermons preached at Brompton to solemnise the papal definition were in just this vein. ${ }^{31}$ Like Faber's, other formal comment on the occasion of the definition displayed the congruence of the mind of the English Catholic leadership with the Roman understanding of the contemporary significance of the act, though with little elaboration. The consistent statement of "the object which the Church . . . had in view in this definition" was a proclamation of Mary's triumph in the cosmic conflict with supernatural evil: "the Woman, it is proclaimed aloud, has crushed his [Satan's] head." ${ }^{32}$ Little elaboration seemed necessary in such expositions. The reader of the Tablet might turn from its first reports of the Roman proclamation of Mary's triumph over "the dominion of . . Satan" to the opposite page which, as it happened, offered an extended discussion of the strategies of that dominion which were characteristic of the nineteenth century. ${ }^{33}$ Such discussions were hardly uncommon as Catholics apparently everywhere became ever more conscious of the Satanic influence exercised over the events and phenomena of their age. ${ }^{34}$

Apocalyptic Marianism was an increasingly important element in English Catholicism: the perception that they were enduring apocalyptic crisis could explain particularly well to English Catholics their minority identity, the hostility they encountered and the character of the society in which they lived. Such confrontation with evil was, at least potentially, their most effective binding force. And it gave purpose as well as solidarity; for it was, as we shall see, intimately connected to their concern for the conversion of their country. The Roman celebration itself presented this prospect: the presence of an archbishop of Westminster, displaying England's return to her place in Christendom, presented a fine picture, as his pastoral recorded, to the mind of the cardinal himself, among others. ${ }^{35}$

29. A complementary Marienbild to that spoken of here, drawn by Faber from a focus on Mary's earthly life, is discovered in F. W. Faber, The Foot of the Cross (London: Burns, Oates and Washbourne, 1857).

30. Undated sermon entitled "The Awfulness of Mary," in "Notes for Sermons \&c . .," unbound Faber Papers, A. L. Orat.

31. Faber, Notes, 2: 403-13.

32. "The Immaculate Conception — Pastoral of the Bishop of Northampton [William Wareing],"

Tablet, 30 December 1854.

33. Tablet, 16 December 1854.

34. G. Cubitt, "God, Man and Satan: Strands in Counter-Revolutionary Thought among Nineteenth-Century French Catholics," in Catholicism in Britain and France since 1789, ed. F. Tallett and N. Atkin (London: Hambledon Press, 1996), 139-41.

35. See also Tablet, 16 December 1854. 
The events of mid-century, of 1854 in particular, bestowed a singular preeminence on the doctrine then proclaimed; but devotion to the Immaculate Conception necessarily returned to its identity as a component of Marianism in general. Indeed, it was doubtless the definition's assertion of the general importance of Marianism, as a system of thought and practice both widely and intensely embraced by Catholics themselves and the aspect of their religion which was most likely to offend against Protestant sensibilities, ${ }^{36}$ which made it most welcome among England's Catholics. That apocalyptic "binary worldview" which is ascribed to the New Catholicism, ${ }^{37}$ if it did not demand actual provocation of the enemy - Secularist or Protestant — certainly required that confrontation which drew clear battle lines: and this recent Marian assertion produced English writings on the topic of the Immaculate Conception which instance the inclination to confrontation well. Understandably, they show little concern with the political dimensions of the general European and American conflict of which the definition was a part. The English confrontation was less with manifestations of the modernity which preeminently constituted the apocalyptic crisis, than with the more important forms of the country's non-Catholic Christianity; but, of course, these were frequently implicated in the sins of modern unbelief. It may be observed, in passing, that what are now perhaps the best known of the period's English Catholic writings on the Immaculate Conception, those penned by John Henry Newman, lack the character just attributed to such writings. There is some indication that had he fulfilled Wiseman's hope and written a substantial piece on the Immaculate Conception, ${ }^{38}$ Newman might have expressed thoughts which better reflected the mind of the contemporary church. ${ }^{39}$ However, his writings on the subject were uniformly addressed to educated and devout individuals of an Anglican background similar to his own (notably Pusey) $)^{40}$ and were intended merely to show that, to such as these, the doctrine was likely to constitute no difficulty. It was a mere extension of doctrines they were already likely to hold, and an unexceptionable one.

That Newman's writings on the Immaculate Conception were addressed to known individuals, gave them a character quite different from the writings on

36. Most contemporary English Protestant responses to the definition reveal little inclination and little ability - to engage in theological discussion of the Immaculate Conception. Protestants who did so, as in the case of Samuel Wilberforce, hardly reckoned it useful to confute individual parts "of a whole system which ... place[s] on the Mediator's throne the Virgin Mother" and thus constituted "one of the most hideous features of Roman superstition." Quoted in J. Jerome, Cuddesden versus Vatican . . . (Paris: J. Leroux et Jouby; London: Burns and Lambert; Richardson and Son, 1855), 26.

37. Clark, "New Catholicism," 39. See also the observations in the introduction to the Selected Works of Juan Donoso Cortés, ed. and trans. J. P. Johnson (Westport, CN: Greenwood Press, 2000), 19-22.

38. M. J. Wilkinson, Frederick William Faber: A Great Servant of God (Leominster: Gracewing, 2007), 148.

39. Newman did reflect somewhat, for example, on the particular capacity of the doctrine to confront the unbelief of the nineteenth century. Newman, Letter to Pusey, 81-82.

40. In addition to the Letter to Pusey, see the writings addressed to Robert Wilberforce and Arthur Osborne Alleyne in Mary: The Virgin Mary in the Life and Writings of John Henry Newman, ed. P. Boyce, 1st English language ed. (Leominster: Gracewing; Grand Rapids: Eerdmans, 2001), 303-333. 
the subject by other Catholics. The latter uniformly served, in their confrontational character, to consolidate and promote the identity of the Catholic community. The Jesuit Thomas Harper produced what came to be regarded of the most reliable vernacular work on the Immaculate Conception. ${ }^{41}$ Like Newman's writings, it was addressed particularly to Anglicans, appropriately, since Harper shared Newman's convert background. Indeed, it indicated obligation to Newman and attempted to elaborate Newman's very briefly stated and undefended understanding of original sin, the tendency of which was clearly to diminish its anthropological consequences. This, Newman had opined, would obviate the difficulty that Protestants encountered in thinking of the Immaculate Conception: an impression that it threatened Mary's identity with the human race. ${ }^{42}$ However, Harper's treatment of this less than brilliant gem of Newman's thought was set in a bezel of militant hostility to Puseyite Anglicanism. It was usual for Catholic authors to deny any distinctiveness to this variety of religion: its adherents were to be called Protestants tout court. ${ }^{43}$ Harper, though, singled out these "Anglican unionists" for attack, anxious to persuade them to abandon their delusive hopes for corporate reunion with the Roman church, nourished by an "entire misconception" of the nature of the church, now dispelled by the manner in which the dogma had been defined. They could now see "the infallible Chair of Peter reared high above the episcopate, as the one centre of unity and pillar of the faith" and with that, their ecclesiology shattered. It was, no doubt, a case of two birds with one stone, since, if the "Gallican erudition" Anglicans deployed had also infected some within the Catholic fold, the matter could here be addressed without manifesting disunity. ${ }^{44}$ As Harper's discussion of the Immaculate Conception continued beyond elaboration of Newman's views on original sin, it was shaped entirely by a design to pursue Pusey through all of his "mistakes" and "erroneous statements" and answer all his objections. ${ }^{45}$

Traditional controversy was, in an age so devoted to it, a fundamental bulwark against Protestant or infidel England and it was inevitable that it was in this genre that most writing on the Immaculate Conception would be done. Frederick Husenbeth - the biographer of a very great controversialist, Bishop John Milner — provided a handbook for Catholics engaging in controversy in

41. This study is to be found in T. Harper, Peace through the Truth: Or, Essays on Subjects Connected with Dr. Pusey's "Eirenicon" (London: Longmans, Green, Reader, and Dyer, 1866), 1: 287-445. The assessment of it is given by E. Bishop, On the Origins of the Feast of the Conception of the Blessed Virgin Mary (London: Burns and Oates, 1904), 3.

42. Harper, Peace through the Truth, 1: 288-316. For Newman's thoughts on the topic of original sin, see his Letter to Pusey, 50-52 and Newman, Mary, ed. Boyce, 318-20. For a concise explanation of the understanding of original sin that Newman apparently embraced - and attributed to his correspondents - see I. A. McFarland, In Adam's Fall: A Meditation on the Christian Doctrine of Original Sin (Chichester: Wiley-Blackwell, 2010), 36-39. The claim that it is particularly consonant with the dogma of the Immaculate Conception must be left to theological debate.

43. It was thus, for example Harper's fellow Jesuit, Peter Gallwey, in his comment on the Eirenicon, chose to dismiss its author. P. Gallwey, The Lady Chapel and Dr. Pusey's Peacemaker ..., 3rd ed. (London: Burns, Lambert and Oates, [1865]), 7.

44. Harper, Peace through the Truth, 1: xcvii, 1 and 289.

45. Harper, Peace through the Truth, 1: 316-98. 
defence of the doctrine. In part, controversy on this topic appealed precisely because this doctrine was difficult to defend by the use of Scripture, at least interpreted in any way acceptable to Protestant polemicists. The circumstance allowed a moving of debate to more fundamental matters, the source of doctrine and the authority of the church. ${ }^{46}$ While, however, the teachings of Protestantism continued to be of much significance to English Catholics, it is noteworthy that the most substantial Irish work on the Immaculate Conception from the period of the definition reflected rather more contemporary Catholic concerns. It was over the infidelity of nineteenth-century Europe, not Protestantism, that Mary's triumph was begged for in the acclamation of the Immaculate Conception. "[T] he ghost of a dead, putrid Protestantism" was now merely joined to "whatever systems there are hostile to the Christian religion" and destructive of civilisation. It was these latter which were provoking the coming "chastisements," a dark age of oppression for the church. Pope Pius sought by means of "a reverent approach to the burning bush, ${ }^{47}$ to save Israel from a second and worse Egypt." 48

However, the apocalyptic dimension of the cultus of the Immaculata was by no means diminished in England; but its chief manifestation showed something of the millennialist aspect it could assume and was a particularly English one; the intense hope for the nation's conversion. The notion seems to have been unwelcome to some of the more conservative and timid among the clergy, who, at least in clerical company, were likely to suggest that the notion sprang from "fanaticism and stupidity"; 49 but it was generally publicly embraced. The hope was no doubt, in part, a merely natural one. If one point was beyond doubt from the speculative and much argued over religious census of 1851, it was that the established church had lost the allegiance of an immense proportion of the population. ${ }^{50}$ There was Anglican alarm at an effectively unchurched population in the lower ranks of society. A mission field had become visible to all. Moreover, it was clear from the spectacular growth of Dissenting bodies, that many were now inclined to choose their own religion. ${ }^{51}$ Had not the Welsh changed their religion, taking the adherents of Dissent from an insignificant minority to an overwhelming majority, in the course of little more than a century? ${ }^{52}$ Catholic missionary activity

46. F. C. Husenbeth, The Chain of the Fathers: Witnesses for the Doctrine of the Immaculate Conception of the Blessed Virgin Mary, Mother of God (London: Thomas Richardson and Son [1860?]), 3-6. See also C. E. Herringer, Victorians and the Virgin Mary: Religion and Gender in England, 1830-1885 (Manchester: Manchester University Press, 2008), 121.

47. The burning bush of Exod. 3: 1-21 is a pre-eminent biblical symbol of the Immaculate Conception.

48. M. Tormey, The Immaculate Conception: An Essay (Dublin: James Duffy, 1855), 5-7. For the author, see J. T. Clare, Priest and Patriot: A Short Sketch of the Life of Michael Tormey, C.C. (Victoria, BC: Trafford, 2004).

49. C. Leetham, Luigi Gentili: A Sower for the Second Spring (London: Burns and Oates, 1965),

68.

50. O. Chadwick, The Victorian Church, pt. 1, 1829-1859, 3rd ed. (London: SCM Press, 1987), 363-69.

51. K. Hylson-Smith, The Churches in England from Elizabeth I to Elizabeth II, vol. 2, 1689-

1833 (London: SCM Press, 1997), 201-202.

52. P. Jenkins, A History of Modern Wales (London: Longman, 1992), chs. 8 and 10. 
could, on occasion, produce positive reports. ${ }^{53}$ Far more importantly, Irish immigration supported an awareness of growth - at least when pastoral zeal transformed Irish religious practice, inchoate by the standards of the nineteenth century. ${ }^{54}$ Yet the approaching conversion of England was uniformly placed in the context of sacred, not profane history. The life of Ambrose Phillipps de Lisle, when its two chief labours are noted, might serve as an illumination of an immensely important constituent part of the Catholic mind of his age. ${ }^{55}$ As his son recalled, he made "[t]he study and contemplation of divine prophecy ... part almost of his everyday life ..." ${ }^{56}$ It was from this that there arose his untiring efforts to advance the conversion of England: the Rosminian, Giovanni Pagini, found that he "spoke of nothing else." ${ }^{\text {" For }}$ Faber, England's conversion was to be accomplished, in its human agents, by their exercising the "power of expiation to thrust aside those tremendous arrears of wrath and judgment which have accumulated against the land for three hundred years of augmenting impurity, profaneness and unbelief.' In its providential aspect, it was a manifestation of mercy in times when events abroad, most vividly in the Papal States, spoke of apocalyptic persecution and apostasy. When the Faith, Faber observed in 1848, appeared "to be ebbing from foreign shores, how fast and freely the tide is flowing in upon our own." ${ }^{58}$ And Faber assuredly held, with his fellow Oratorians, Newman and Edward Caswell, who recorded their conviction in charming verse, that providence designed that the principal role in the unfolding drama of the conversion of England would be Mary's. ${ }^{59}$ In 1893, the Redemptorist Thomas Bridgett recalled Newman's by now famous Second Spring sermon, with its call to Mary to "arise ... and go forth in thy strength into that north country, which once was thine own ..." ${ }^{60}$ The context of Bridgett's quotation was his sermon, preached before Cardinal Vaughan and the other bishops of England, on the occasion of a renewal of England's dedication to the Virgin. This, England's second great public manifestation of Marian devotion in the nineteenth century, like that of 1854 , took place in the Brompton Oratory. There was indeed no radical change in the character of the devotion manifested; but the shifts in emphasis are noteworthy.

53. Leetham, Gentili, ch. 6 passim.

54. See also S.W. Gilley, "Irish Catholicism in Britain," in Religion, State and Ethnic Groups, ed. D. Kerr et al. Comparative Studies of Governments and Non-Dominant Ethnic Groups in Europe, 1850-1940, vol. 2 (Aldershot: Dartmouth Publishing, for the European Science Foundation, 1992) $237-42$

55. A modern biography has been provided by M. Pawley, Faith and Family: The Life and Circle of Ambrose Phillipps de Lisle (Norwich: Canterbury Press, 1993).

56. E. S. Purcell and E. de Lisle, Life and Letters of Ambrose Phillipps de Lisle (London: Macmillan, 1900), 2: 105.

57. Leetham, Gentili, 126.

58. Faber, Notes, 1: 357 and 361.

59. N. M. de Flon, "Mary and Roman Catholicism in Mid Nineteenth-Century England: The Poetry of Edward Caswall," in The Church and Mary: Papers Read at the 2001 Summer Meeting and the 2002 Winter Meeting of the Ecclesiastical History Society, ed. R. N. Swanson (Woodbridge: Boydell Press, for the Ecclesiastical History Society, 2004), 308-18.

60. T. E. Bridgett, England for Our Lady: A Sermon ... (London: Burns and Oates, [1893]), 3. 


\section{The Consecration of England}

Apocalyptic belief, in transcendent religions, universally creates or confirms a distinct identity: that of the faithful body of believers to be vindicated by the coming manifest supernatural intervention, but now afflicted in the crisis which will provoke it. ${ }^{61}$ And that identity - frequently well expressed by applying the biblically derived term "remnant" to it - has been invaluable in the creation and maintenance of communal solidarity and purpose. The historical self-perception of English Catholics and the social and intellectual hostility they encountered, as well as their mere numbers, do much to explain the growth - more marked than in other Catholic churches of the nineteenth century - of such an identity among them. If we are to discuss this remnant identity in speaking of nineteenth-century English Catholicism, it is certainly to its Marianism that we must look. However, what is strongly suggested by examining the great public declaration of Marian devotion made in 1893 is the observable weakening of this identity. It was hardly that the warfare between the church and "modern civilisation" was now any less inevitable than Pius IX had endeavoured to make plain to both his followers and his enemies when he issued the Syllabus. But there did seem to be a weakening of the morale and zeal of English Catholic combatants, which provoked some anxiety.

Such anxiety was justified. In part, it is to be explained by the diminished hostility the Catholic body now encountered. When, towards the end of the century, the Catholic population approached some 5 per cent of the whole, their religion and persons had become a part of the daily landscape in England and occasioned less hostility. Considering a group of texts expressing various external views of Catholicism, Erik Sidenvall contrasts the decades around mid-century, when anti-Catholicism was "hegemonic," with the 1890s. "Tolerance now lived side by side with anti-Catholicism." A "tolerant discourse" was now at least available, even if its future hegemony could not be taken for granted. ${ }^{62}$ The editor of the Tablet, John Snead-Cox, lamented "the work done by the great solvent, toleration" in a Catholic body now in "a period of what looks like social disintegration." The intended assertive display of Marian devotion would be "a great corporate action ... [constituting] a demonstration in the face of the world," and in particular an uncomprehending and hostile England. It could thus be commended as a useful remedy against the ill he diagnosed. Significantly, the editorial made no reference to any supernatural benefits sought from the act of Marian consecration. ${ }^{63}$ Snead-Fox's anxiety and the purpose he sought to give the approaching event undoubtedly mirrored the thinking of those who organised it. It lay at the heart of the Catholic church's contemporary mission to create of each local church a society with a distinct intellectual and cultural identity which served as "a functioning counterweight

61. B. McGinn, "Early Apocalypticism: The Ongoing Debate," in Apocalypticism in the Western Tradition (Aldershot: Variorum, 1994), 10-11.

62. E. Sidenvall, After Anti-Catholicism? John Henry Newman and Protestant Britain, 1845c.1890 (London: T. \& T. Clark, 2005), 174-80.

63. Tablet, 3 June 1893. 
to modern secular society." ${ }^{64}$ The pursuit of this end was integral to almost all the thought of its leadership, clerical and lay. Thus, it was inevitable that the consecration, when proposed, was made instinctively to serve as a display of a distinctive Catholic culture that confirmed the separate identity of the Catholic community.

A permeating concern with the condition of the Catholic body in England and a desire to strengthen its separate identity are what most obviously mark off the consecration of 1893 from the celebration of the definition of the Immaculate Conception forty years before. At that time attention had been focused on the apocalyptic crisis afflicting the universal church, or, more particularly, Mary's role in that crisis, and the spiritual exertions demanded of English Catholics if their country was to play its expected part, as a Catholic nation, in the supernatural upheavals of the age. ${ }^{65}$ That the millennialist expectation of the swift conversion of England remained unfulfilled may no doubt be said to have constituted a reason, in addition to a numerical growth and a more tolerant environment, for the lamented condition of the English Catholic community. However, it should be noted too that if the optimistic element in the Catholic apocalyptic of mid-century had faded away, the pessimistic vision of an apocalyptic crisis constituted by modern, secular society had not. The English Catholics remained, even if the earnestness of their expectation was reduced, a remnant community, awaiting an apocalypse. Lord Braye, in 1892, expressing his disapproval of the English Catholic church's structures, appropriate only to the territoriality practised by religious establishments, castigated the "delusion" of a previous generation "that England would rapidly return to the Faith" as the source of the misguided development policy. However, if he had, as he suggested, given up any belief in the possibility of converting a considerable portion of his fellow countrymen, it was because he perceived a society around him marching to destruction in an abyss of moral decay occasioned by unbelief, which encompassed Protestantism's apostasy from Christianity. England was now so debilitated that it could no longer respond to the Catholic church's call. ${ }^{66}$ This perception was commonplace and echoed authoritatively. The new archbishop of Westminster, Cardinal Vaughan, predictably struck a more positive note than Lord Braye: speaking of a "partial conversion" of England already accomplished, he expressed hope for the future. ${ }^{67}$ Nevertheless, Vaughan decidedly shared the apocalyptic outlook of his predecessor in Westminster, Henry Manning, and gave it more coherent form by his adherence to the practical, devotional Mariology of Grignion de Montfort, with whose teaching he was anxious to arm his priests, in both Salford and Westminster, in preparation for the last days in which "the struggle

64. Schaefer, "Catholic Wissenschaft": 434

65. See, for example, Faber, Notes, 1: 361.

66. A. T. Verney-Cave (the Lord Braye), preface to T. Murphy, The Position of the Catholic Church in England and Wales during the Last Two Centuries: Retrospect and Forecast (London: Burns and Oates; New York: Catholic Publications Society, 1892), 5-13.

67. H. Vaughan, A Pastoral Letter on the Queen's Jubilee (London: Secretary, Archbishop's House, 1897), 7. 
between good and evil shall become intensified." ${ }^{68}$ The new cardinal's belief that these days were at least prefigured in his own was made clear when he addressed his people on the subject of their civic duties. The "modern civilisation," denounced in the Syllabus, was now at the point of dissolution, while adherents of forms of religion influenced by the ideas of the Enlightenment uttered "cries of almost satanic rage" against the teachings of authentic Christianity ${ }^{69}$ The defence of the corporate integrity of English Catholics in the face of a society thus perceived and the taking of precautions against any lowering of barriers to integration with it were surely admirable purposes.

It may well be said that the events attending the consecration of 1893 are best distinguished from those attending the definition of 1854 in that they speak primarily of the recent history of English Catholics, as perceived by their contemporary leaders, rather than of Marian thought and devotion, albeit that neither this perception nor the event itself is explicable without attention to a pattern of apocalyptic thought — the subject matter of the present article - in which Marianism held a pre-eminent place. The notion of a consecration of England certainly did not arise immediately from Marian piety, but in a desire to express devotion and fidelity to Leo XIII, which was spontaneously expressed in Marian form. Emphasis on communal loyalty to the person of the pope remained throughout.

In February 1893, the duke of Norfolk led a national pilgrimage to Rome, where, ostensibly, the pope himself, in responding to the English address, made the proposal of a consecration to both the Mother of God and Saint Peter. The consecration, Vaughan declared, was a continuation of this "recent stir and outburst of Catholic love [for] and loyalty" to the pontiff and took its form from his "express instruction." "70 The notion of a national consecration, when brought forth, probably possessed an appeal derived from a familiarity with contemporary French Catholicism and displayed an understanding among English ecclesiastics that Leo XIII's ralliement was merely a matter of international politics and did not reflect any papal desire to reassess the church's relationship to the age. A national consecration to the Virgin had a well-known precedent in France, depicted in Ingres' painting of 1824, “The Vow of Louis XIII." More important was the enduring zeal among French Catholics for the consecration

68. H. Vaughan, "Preface to the Fifth Edition," in L.-M., Grignon [sic] de Montfort, A Treatise on the True Devotion to the Blessed Virgin, trans. F. W. Faber, 8th ed. (London: Burns and Oates; New York: Benziger Brothers, 1892), xxvii. See also H. Vaughan, "Allocution in the 31st Synod, of 1892," in Synodus Dioecesana Westmonasteriensis Trigesima Secunda (Salford: J. Roberts and Sons, 1893), 14. Manning's apocalypticism seems to have been less specifically Marian and most likely to be manifested chiefly in the context of his observation of contemporary affairs. See, for example, undated "Notes on the Warfare of the World ag[ain]st the Church," Manning Papers, Ma. 10/5, Archives of the Archbishops of Westminster, Kensington.

69. H. Vaughan, Catholics and their Civic Duties (London: Secretary, Archbishop's House and Burns and Oates, 1894), 5-6 and 8.

70. The Consecration of England to the Mother of God and to the Prince of the Apostles: A Letter from the Cardinal Archbishop and Bishops of the Province of Westminster (London: Burns and Oates, 1893), 5. See also, H. Vaughan, On the Roman Pilgrimage ... (London: Secretary, Archbishop's House and Burns and Oates, 1893). An emphasis on the consecration as a response to "the words of the Supreme Head of Christendom" was duly echoed in the Tablet's reporting of the event. See Tablet, 1 July 1893. 
of their country to the Sacred Heart, which had been at its most intense in the nineteenth century. Adherence to this crusade, calling all France to make reparation to the Sacred Heart for the sins of its revolutionary past and its continuing impenitence - thus delaying "the promised Christian millennium" for this "chosen people" - had become a most notable manifestation of a militant and divisive Catholicism, that sought the destruction of the ascendant secularising forces of the Third Republic. ${ }^{71}$ Bridgett, in his sermon at the consecration, had little difficulty in translating this French tradition to England. He argued that the recent development of English devotional life, Marian and Eucharistic, no less than devotion to the Sacred Heart, was intended to serve "the work of reparation." The Catholic commonplace that the Enlightenment and secular modernity had their origins in the Reformation allowed a fusion of the sins of Protestant England with those more recent sins sprung from French and Italian apostasy. All alike required expiation. ${ }^{72}$

A national consecration demanded English, and thus medieval, rather than contemporary Roman apparel. Vaughan, though he found his own devotional and pastoral inspirations in the era of the Counter-Reformation, ${ }^{73}$ joined in commending this. ${ }^{74}$ The act of consecration was to be a renewal of a medieval consecration of England as the dos Mariae - the Dowry of Mary - identified, conjecturally, as an act of royal petition or thanksgiving for the suppression of Wat Tyler's revolt. ${ }^{75}$ Bridgett owed his choice as preacher to his voluminous but popular work with the title, Our Lady's Dowry, which — together with the work of the antiquary Edmund Waterton - ably endeavoured to carve a place for Marian devotion in the vast range of nineteenth-century English medievalist interests. ${ }^{76}$ In view of this scholarly work, the medievalism of the consecration ceremony could be seen by its organisers as having substantial devotional content, in a fashionable form. Bridgett's sermon then, though it also responded to contemporary disillusionment about the conversion of England ${ }^{77}$ and, as noted above, spoke of modern evils, had to retain a medievalist focus. And the medievalist theme was maintained, as best it could be in the neobaroque surroundings of the Brompton Oratory, in other ways. The Tablet displayed a marked interest in the cardinal's dress during the ceremonies: in his mitre, once that of Thomas Becket; in his ring, in which was set another relic

71. R. Jonas, France and the Cult of the Sacred Heart: An Epic Tale for Modern Times (Berkeley and Los Angeles: University of California Press, 2000). See especially 140-41.

72. Bridgett, England for Our Lady, 25-29. Continuing interest in this historical theme is indicated by B. S. Gregory, The Unintended Reformation: How a Religious Revolution Secularized Society (Cambridge, MA: Belknap, 2012).

73. J. G. Snead-Cox, The Life of Cardinal Vaughan (London: Herbert and Daniel, 1910), 1: 389 and 415-53. Snead-Cox's life should not be mentioned without drawing attention to the much more recent research of R. O'Neill, Cardinal Herbert Vaughan: Archbishop of Westminster, Bishop of Salford, Founder of the Mill Hill Missionaries (Tunbridge Wells: Burns and Oates, 1995).

74. The Consecration of England, 6-10.

75. Bridgett, England for Our Lady, 15-21. Bridgett's account of the origin of the designation of England as the dos Mariae remains acceptable. See D. Gordon et al., Making and Meaning: the Wilton Diptych (London: National Gallery Publications, 1993), 21, 57-58 and 60.

76. T. E. Bridgett, Our Lady's Dowry: How England Gained that Title, 3rd ed. (London: Burns and Oates; New York: Catholic Publications Society, [1890]).

77. Bridgett, England for Our Lady, 22-25. 
of that saint; and in a gothic cope. Its medievalism, the journal's editor declared, made of the consecration a pedagogy, adding historical depth to contemporary Catholic mores and devotions, necessarily alien to "those who have grown up in the ways of the modern schism." Medievalism could be said to communicate "a new sense of corporate identity and kinship with our Catholic fathers"; but it also served to mark a lack of shared identity with modern England. ${ }^{78}$ And other merits might be found in return to the Middle Ages. It served to reprove the internal dissent of carping Gallicans, "only in name Catholics," who found excess in contemporary devotion to the Virgin and slighted it as novel and "Italianate." A major purpose of Waterton's work had been to show that, on the contrary, this was a mere revival of an ancient and indigenous English tradition of devotion, not a whit less "fervent and outspoken" than that to be observed in contemporary Latin Europe. ${ }^{79}$ Such scholarship as that of Waterton, the Tablet observed, helped "all individually to realise as we have never done, in how true a sense we belong to an unchanging Church." $" 80$

\section{Conclusion}

The English Catholic Church in the nineteenth century derived what importance it possessed - and therefore derives a deal of its historical interest from the church of which it was a part and the nation of which it was a part. These relationships, to Rome and to England, must certainly be looked on as chief determinants of its history, in our writing of it. Certainly, concern with English Catholic conformity to dominant trends, which we might conveniently lump under the heading of "Ultramontanism" and which mirrored those equally dominant throughout the Catholic world, are more deserving of attention than dissent from those trends, which had little impact. The great public Marian events of the second half of the nineteenth century commented on here speak well of both this relationship to the universal church and the much more negative, or at least equivocal relationship to contemporary England.

The English celebration and reception of the papal definition of December 1854 exemplify an enthusiastic identification with the prevailing tendencies in Catholic thought in the age of Pius IX, which were particularly congruent with the needs of English Catholicism. The definition constituted, chiefly, an expression of apocalyptic belief that was of particular significance to the small, socially coherent body of English Catholics. Their identity as a faithful remnant, awaiting the vindication that would come with divine intervention, was strengthened with expectations of the nation's imminent conversion, a strain of thought imbued with Marianism. The long struggle with Protestant England could now be seen to be part of a cosmic one. There were no doubt many English Catholics who could share the view of their country adopted by

78. Tablet, 3 June and 1 July 1893.

79. E. Waterton, Pietas Mariana Britannica: A History of English Devotion to the Most Blessed Virgin Marye [sic] . . . (London: St. Joseph's Catholic Library, 1879), first pagination, 3.

80. Tablet, 1 July 1893. 
Don Giacomo Margotti, the editor of Turin's L'Armonia, even if they would, in prudence, have avoided elaborating their thoughts in public. Nineteenthcentury England, as a symbol and champion of the paganism of the civitas terrena, stood as a pre-eminent combatant in a struggle against the Roman manifestation of the civitas Dei.$^{81}$ Catholics in the citadel of the enemy, though, conducted the struggle in rather unspectacular ways. There was a continuation and intensification of the Catholic-Protestant polemic that had raged from the Reformation to the time of Bishop Milner; there was a reinforcing of walls, probably made firm enough by the anti-Catholicism of the English and their contempt for the Irish. Still, such hostility was a useful enough contribution to Catholic solidarity.

If the events of 1854 depict English Catholics in a thoroughly positive relationship with the church of Pio Nono and inclined to regard the society around them with marked hostility, those of 1893 display, certainly not an abandonment of these positions, but a perception that they were, at least, being undermined. English Catholics' zeal and solidarity could be seen as diminished: and the phenomenon is chiefly to be attributed to a diminished supernatural, or more precisely, apocalyptic vision of the world they inhabited. The very act of asserting their Marianism in the act of consecration, when this is examined, amounted to an acknowledgment that loss had been sustained and ground needed to be recovered. The constant threat to Rome - "the holy city," as Faber habitually referred to it - in the decades before 1870, a topic never far from English newspaper headlines, had sustained apocalyptic anxiety; the situation of the Prisoner of the Vatican could not. The consecration of 1893 constituted a very deliberate attempt to renew devotion to the pope. The conversion of England was no longer used in a complex of apocalyptic beliefs; but the sense of purpose the idea gave and the Marianism with which it was bound up could not be lost. And if such thought among the leaders of English Catholicism does much to explain the consecration of 1893, so too does their wider awareness that Catholics, increased in numbers, were now much more widely diffused through English society and no longer certain to encounter a hostile environment in it. The consequence, it was felt, would be a loss of fervour and purpose. In brief, the years at the end of the nineteenth century may well manifest the victory of nineteenth-century Ultramontanism and triumphalism; but the display of these things concealed a well-founded anxiety that English Catholics were already suffering a loss of the fervour manifested at mid-century and were now threatened with assimilation to a society which, even in its very toleration of them, was inimical to their identity, beliefs, and values.

81. G. Margotti, Roma e Londra confronti (Turin: Fory e Dalmazzo, 1858).

(C) 2014 The Author 